\title{
ORIENTASI KEWIRAUSAHAAN DALAM BISNIS KELUARGA
}

\author{
HEMA DiAn ULFA \\ MADE Siti SundARI
}

FAKULTAS BISNIS DAN EKONOMIKA, UNIVERSITAS

SURABAYA

EO merupakan tindakan-tindakan yang kreatif, proaktif, dan berani mengambil risiko dalam strategi pengambilan keputusan (Keh, Nguyen, \& Ng, 2007). Dimensi dalam EO tersebut mempunyai hubungan positif, termasuk pengambilan risiko (Naldia, Nordqvist, Sjoberg, \& Wiklund, 2007). Perilaku tersebut diharapkan memiliki efek langsung maupun tidak langsung pada profitabilitas perusahaan (Barker \& Sinkula, 2009). EO adalah untuk meningkatkan hasil keuangan dari pada untuk memajukan tujuan lain yang dapat diikuti oleh organisasi dan manajer mereka. (Rauch, Wiklund, Lumpkin, \& Frese, 2009). EO juga berorientasi pada kinerja perusahaan yang lebih kompleks, bukan hanya indikator keuangan saja (Wiklund \& Shepherd, 2005).

Sebuah usaha bisa disebut bisnis keluarga jika ada keterlibatan anggota keluarga baik dalam hal kepemilikan ataupun dalam dimensi manajemen dalam mengambil keputusan (Aloulou, 2018). Peranan orientasi kewirausahaan dalam bisnis keluarga tergantung dari pemahaman terhadap pembelajaran organisasi dalam keluarga tersebut (Wang, 2008).

Peranan orientasi kewirausahaan juga ditunjukan oleh orientasi strategis keluarga, gaya, metode serta praktek pengambilan keputusan Pengaruh eo terhadap adalah EO mengacu pada orientasi strategis perusahaan dalam mengalokasikan sumber daya yang berbasis pengetahuan (Wiklund \& Shepherd, 2003).

Bisnis keluarga adalah orientasi untuk menuju tujuan dalam waktu jangka panjang untuk kepentingan generasi yang akan mendatang atau berhubungan positif dengan investasi dalam inisiatif keberlanjutan ( Mullens, 2017). Dalam bisnis keluarga, meskitpun setiap anggota keluarga mempunyai peranan masing-masing, namun sosok anggota keluarga perempuan dalam keluarga tersebut sangat menentukan bisa membawa perusahaan tersebut apakah bisa survive (Jurik, Krizkova, \& Pospisilova, 2015).

Dalam perusahaan keluarga, kinerja perusahaan (FP) merupakan konsep yang nonmonotonik bukan hanya saat sebuah keluarga memulai usaha baru tetapi juga ketika bisnis keluarga tersebut berkembang dalam periode lebihd ari 50 tahun (Reeb \& Anderson, 2003). Dalam bisnis keluarga, kinerja perusahaan merupakan sebuah negasi 
dari ukuran kinerja perusahaan yang bisa secara subyektif disebut tinggi, atau di atas rata-rata kinerja dalam industri yang sama (Primc \& Cater, 2015). Kinerja perusahaan keluarga juga bisa berarti keuntungan kolaboratif untuk dengan perusahaan perusahan lain yang lebih kecil. (Cao \& Zhang, 2011).

Kinerja perusahaan adalah dimoderasi oleh jenis kepemilikan dan otonomi dalam kepegawaian perusahaan-perusahaan. (Wei \& Lau, 2008). Keberhasilan sebuah perusahaan dalam menerapkan konsep-konsep orientasi bisa dipengaruhi oleh perubahan jenis pekerjaan. (Madsen, 2007).

Dalam bisnis keluarga, EO menentukan antara hubungan dan nilai dari kedua sistem, termasuk hubungan saling percaya, yang menghasilkan relasi yang unik dalam organisasi dalam jangka panjang. (Shi, Shephred, \& Schmidts, 2015). Pengaruh orientasi kewirausahaan di perusahaan keluarga menentukan visi jangka panjang lintas generasi melalui pengembangan kemampuan setiap anggota keluarga (Cruz \& Nordqvist, 2012). Namun demikian, perusahaan keluarga beroperasi secara relatif konservatif, sehingga orientasi ke pemilik dan kurang menguntungkan dan berorientasi pada pertumbuhan dan lebih berisiko dibandingkan perusahaan non-keluarga. (Kickul et al, 2010).

Pengaruh orientasi kewirausahaan dalam bisnis keluarga ditentukan oleh mekanisme eksploitasi pengetahuan pada anggota keluarga yang berdampak pada kinerja perusahaan (Chaudhary \& Batra, 2017). Perusahaan keluarga cenderung mengadopsi strategi yang menghindari ketika dalam kondisi krisis, namun bisa juga berbeda tergantung preferensi anggota keluarga tersebut dalam mengambil risiko (Memili, Fang, \& Welsh, 2015). Kewirausahaan dari perusahaan milik keluarga atau bisnis keluarga, dan hubungan antara kinerja perusahaan keluarga, etika, dan keterlibatan. (Alonso \& Austin, 2016).

Correspondent author: madesiti@staff.ubaya.ac.i

\section{BIBLIOGRAPHY}

Mullens, D. (2017). Entrepreneurial orientation and sustainability initiatives in family firms. Journal of global responsibility, 160-178.

Alonso, A. D., \& Austin, I. (2016). Entrepreneurial CSR in the context of a regional family firm: a stakeholder. Annals in social responsibility, 48-62.

Aloulou, W. J. (2018). Examining entrepreneurial orientation's dimensions - performance relationship in saudi family businesses. Journal of family business management, 126145.

Barker, E. W., \& Sinkula, J. M. (2009). The Complementary Effects of Market Orientation and Entrepreneurial Orientation Profitability on Small Businesses. Journal of Small Business Management, 443-464. 
Cao, M., \& Zhang, Q. (2011). Supply chain collaboration: Impact on collaborative advantage and firm performance. Journal of Operations Management, 163-180.

Chaudhary, S., \& Batra, S. (2017). Absorptive capacity and small family firm performance: exploring the mediation processes. Journal of knowledge management, 1201-1216.

Cruz, C., \& Nordqvist, M. (2012). Entrepreneurial orientation in family firms: a generational perspective perspective. The entrepreneuring family, 3-49.

Kickul, J., Liao, J. (Jon), Gundry, L., \& lakovleva, T. (2010). Firm resources, opportunity recognition, entrepreneurial orientation and performance: the case of Russian women-led family business, International Journal of Entrepreneurship and Innovation Management, 12(1) 7-97.

Jurik, N., Krizkova, A., \& Pospisilova, M. (2015). Czech copreneur orientations to business and family responsibilities: a mixed embeddedness perspective. International journal of gender and entrepreneurship, 307-326.

Keh, H. T., Nguyen, T. M., \& Ng, H. P. (2007). The effects of entrepreneurial orientation and marketing information on the performance of SMEs. Journal of Business Venturing, 592-611.

Madsen, E. L. (2007). The significance of sustained entrepreneurial orientation on performance of firms - A longitudinal analysis. Entrepreneurship \& Regional Development: An International Journal, 185-204.

Memili, E., Fang, H. C., \& Welsh, D. H. (2015). Value creation and value appropriation in innovation process in publicly-traded family firms. Management Decision, 19211952.

Naldia, L., Nordqvist, M., Sjoberg, K., \& Wiklund, J. (2007). Entrepreneurial Orientation, Risk Taking,and Performance in Family Firms. Family Business Review, 33-47.

Pratono, A. H., \& Mahmood, R. (2015). Mediating effect of marketing capability and reward philosophy in the relationship between entrepreneurial orientation and firm performance. Journal of Global Entrepreneurship Research, 5(5), 1-12.

Pratono, A.H. (2016). "Strategic orientation and information technological turbulence: Contingency perspective in SMEs", Business Process Management Journal, 22(2), 368-382, https://doi.org/10.1108/BPMJ-05-2015-0066

Pratono, A.H. \& Tjahjono, G. (2017) "How does materialistic attitude influence the impact of corporate brand on the customers' intention to donate to corporates' charity?, Humanomics, 33(4), 484-498, https://doi.org/10.1108/H-07-2016-0052

Pratono, A.H., Suyanto, Marciano, D., \& Zurbrügg, C. (2017). Social return on investment for community-based enterprise in Surabaya City, The Hong Kong Journal of Social Work 51 (01n02), 93-114 
Pratono, A.H., (2018) Does firm performance increase with risk-taking behavior under information technological turbulence?: Empirical evidence from Indonesian SMEs", The Journal of Risk Finance, 19(4), 361-378, https://doi.org/10.1108/JRF-10-2017$\underline{0170}$

Pratono, A.H. (2018). From social network to firm performance: The mediating effect of trust, selling capability and pricing capability, Management Research Review 41 (6), $680-700$

Pratono, A.H. (2018). Linking religiosity to citizenship behaviour under materialism attitude: Empirical evidence from Indonesia", International Journal of Ethics and Systems, https://doi.org/10.1108/IJOES-07-2018-0104

Pratono A.H. (2018). Network structure and open innovation: the role of trust in product development International Journal of Business Innovation and Research, 15 (1), 4461.

Pratono, A.H., Ratih, R.V.S., Arshad, D. (2018). Does Entrepreneurial Autonomy Foster SME Growth Under Technological Turbulence? The Empirical Evidence from Indonesia, Journal of Technology in Behavioral Science, 3(3), 170-178.

Primc, K., \& Cater, T. (2015). Environmental Proactivity And Firm Performance, a fuzzyset analysis. Management Decision, 648-667.

Rauch, A., Wiklund, J., Lumpkin, G., \& Frese, M. (2009). Entrepreneurial Orientation and Business Performance, An Assessment of Past Research and Suggestions for the Future. Enterpreneurship Theory and Practice, 761-787.

Reeb, D. M., \& Anderson, R. C. (2003). Founding-Family Ownership and Firm Performance: Evidence from the S \& P 500. The Journal of Finance, 1301-1328.

Shi, H. X., Shephred, D. M., \& Schmidts, T. (2015). Social capital in entrepreneurial family businesses: the role of trust. Social capital in entrepreneurial family businesses: the role of trust, $814-841$.

Wang, C. (2008). Entrepreneurial Orientation, Learning Orientation, and Firm Performance. Entrepreneurship Theory and Practice, 32(4), 635-657. , 635-657.

Wei, L.-Q., \& Lau, C. -M. (2008). The impact of market orientation and strategic HRM on firm performance: the case of Chinese enterprises. Journal of International Business Studies, 980-995.

Wiklund, J., \& Shepherd, D. (2003). Knowledge-based resources, entrepreneurial orientation, and the performance of small and medium-sized businesses. Strategic Management Journal, 1307-1314.

Wiklund, J., \& Shepherd, D. (2005). Entrepreneurial orientation and small business performance: a configurational approach. Journal of Business Venturing, 71-91. 